\title{
CORRESPONDENCE
}

\section{SUBCONJUNCTIVAL AB EXTERNO APPROACH IN GLAUCOMA}

\section{To the Editors of the BRITISH JOURNAL OF OPHTHALMOLOGY}

DeAR'SIRS-In pursuance of Mr. Eugene Wolff's article on " The Subconjunctival ab externo Approach in Glaucoma " (British Journal of Ophthalmology, 33, 514, 1949), I feel that the following article published in Poland in 1932 by Dr. Adam Zamenhof may be of interest. I was one of his assistants and worked with him for many years. In presenting this translation I wish to pay homage to an outstanding ophthalmologist who lost his life during the last war.

\section{Yours faithfully,}

\section{7, Dudley Court, \\ UPPER BERKELEy STREeT, LONDON, W.1.}

January 11, 1952.

\section{I. Mantinband.}

\section{SCLEROTOMY $A B$ EXTERNO IN OPERATIONS FOR GLAUCOMA}

By AdAm ZAmenHof, translated and abridged from Klinika Oczna, 10, 146 (1932) by M. I. Mantinband.

Sclerotomy ab externo, which is carried out more frequently now than in the past, is mainly used in cases of glaucoma.

When the anterior chamber is shallow the incision made by a Graefe knife is difficult to perform and the lens may easily be injured. In such cases Elschnig (1928) recommended an incision $a b$ externo made by a special knife. Even in cases with a normal anterior chamber he used this method to avoid possible damage to the lens and iris. During this procedure the outflow of fluid is slower and more gradual, which is a very important point because in glaucomatous eyes the sudden change of tension may cause severe haemorrhages. Zirm $(1925,1929)$ and Kapusćinski held the same opinion. Salzmann (1930) examined many excised eyes and arrived at the conclusion that the main cause of unsuccessful results in iridectomy lay in the damage done to the anterior capsule. He tried to incise the sclera above the margin of the cornea; this resulted in the prolapse of the iris, so that it was not necessary to enter the anterior chamber with instruments. Then he used to seize the iris with forceps and cut it away. Terson may be mentioned among the French followers of this method. Weekers (1931) makes a perpendicular incision for iridencleisis.

Experience shows that if the knife is inserted only a little more than $1.25 \mathrm{~mm}$. the ciliary body will be injured. This risk is obviated by a special instrument invented by Dr. Adam Zamenhof. A Gillette razor blade is encased in an oblong metal frame. When both sides of this frame are closed, the edge of the blade protrudes only $1.2 \mathrm{~mm}$. and it is thus impossible for the incision to go any deeper. This instrument is very cheap to make and the razor blade easy to obtain. 


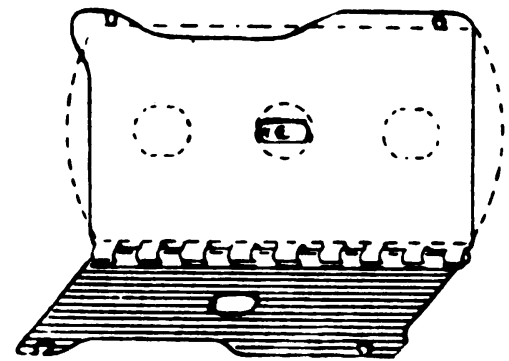

(a)

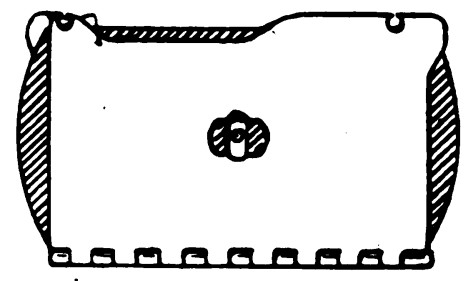

(b)

FIGURE.-Drawing of Zamenhof's sclerotomy knife. (a) Frame open showing position of razor blade. (b) Frame closed showing instrument ready for use (actual size).

Technique

(1) Akinesia of the orbicularis muscle.

(2) Local Anaesthesia.-The pupil has to be small, and for this purpose 3 to 4 drops gutt. eserini $\$$ per cent. should also be instilled.

(3) Retrobulbar Injection ( 2 per cent. Novutox plus adrenaline).-This is sometimes required to decrease the tension.

(4) Intramuscular Injection. - 2 per cent. Novutox plus adrenaline is injected over the belly of the superior rectus, through which a black suture is afterwards passed.

\section{Iridectomy}

The eyeball should be immobilized. The instrument described above must be held in the right hand with the sharp edge nearer to the nose. The surface of the knife should be perpendicular to the globe. The incision is made at the margin of the cornea, the knife being manipulated slowly. In eyes with higher tension we can observe during this procedure a slight outflow of fluid. The instrument must be removed from the wound slowly. Sometimes a slight prolapse of the iris occurs, which is desirable in iridectomy or iridencleisis. The remaining procedure is as in a classical iridectomy.

\section{Sclerecto-Iridectomy}

A large conjunctival flap is made. The instrument is held a little obliquely, at an angle of $45^{\circ}$, and the episclera is scraped away to the margin of the cornea, where the knife is stopped. This is the place which Lagrange called the zone décollable. The knife should now be held perpendicular to the surface of the globe, and then the incision, sclerectomy, and iridectomy should be performed. The sclera is cut away with a punch before iridectomy, because the iris serves as a protection for the ciliary body. The punch must not be introduced deeper than $1 \mathrm{~mm}$.

During 1931--32, 220 operations were performed with this instrument. In 105 cases of acute glaucoma, the intra-ocular tension remained normal after iridectomy. In chronic glaucoma a permanent filtration (good drainage) and normal tension were observed.

\section{REFERENCES}

Elschnig, A. (1928). Klin. Mbl. Augenheilk., 80, 382.

SalzmanN, M. (1930). Z. Augenheilk., 72, 127.

Weekers, L. (1931). Arch. Ophtal., Paris, 48, 593.

ZIRM, E. (1925). Klin. Mbl. Augenheilk., 75, 725. (1929). Ibid., 82, 93. 